\title{
Cooperation among intergovernmental organizations in global cultural governance: Towards an actor-centered constructivist approach
}

\section{Antonios Vlassis}

To cite this article: Antonios Vlassis (2022): Cooperation among intergovernmental organizations in global cultural governance: Towards an actor-centered constructivist approach, International Journal of Cultural Policy, DOI: 10.1080/10286632.2021.2014461

To link to this article: https://doi.org/10.1080/10286632.2021.2014461

曲 Published online: 05 Jan 2022.

Submit your article to this journal $\widetilde{1}$

Q View related articles $\longleftarrow$

View Crossmark data $\asymp$ 


\title{
Cooperation among intergovernmental organizations in global cultural governance: Towards an actor-centered constructivist approach
}

\author{
Antonios Vlassis \\ Center for International Relations Studies, University of Liege, Belgium
}

\begin{abstract}
This article provides an empirical investigation of the cooperation among intergovernmental organisations (IOs) in global cultural governance. The existing scientific literature has not yet taken up the inter-organisational cooperation as a serious topic of research and the present contribution aims to fill this gap. Based on an actor-centred constructivism, the article seeks to address inter-organisational cooperation as an observable empirical phenomenon, to explore when and why the cooperation between IOs risks not lasting and to understand why the dynamics of inter-organisational cooperation in cultural affairs have a specific-time limit. The focus will be on two cases: the European Union-Mercosur audiovisual programme and the United Nations interagency group on creative industries. As such, the article is more concerned with analysing the political micro-foundations through which the cooperation among IOs takes place and with exploring the factors, which contribute to not establish sustainable cooperative arrangements.
\end{abstract}

\section{ARTICLE HISTORY}

Received 12 May 2021

Accepted 1 December 2021

\section{KEYWORDS}

Intergovernmental organizations; actorcentered constructivism; global cultural governance; cultural industries; European Union; UNESCO

In September 2020, the European Union (EU) in partnership with the Organisation of African, Caribbean and Pacific (ACP) States and the Organisation internationale de la Francophonie announced a new funding mechanism in support of audiovisual co-productions between ACP and EU countries. The mechanism is funded with 10 million euros by the ACP-EU Culture Program. Besides, in April 2019, the ACP-EU Culture Program published its first call of the program 'Support for ACP Audiovisual Co-production' with an initial budget of 5.8 million euros.

'There is potentially no issue of global or transnational dimension in which international organisations are not involved' (Brosig 2011, 147). Intergovernmental organisations (IOs) ${ }^{1}$ play an increasing role in the distribution of ideas, norms and resources within the global cultural governance (Vlassis 2015a; De Beukelaer and Spence 2019). The cooperation between IOs is a well-established reality in cultural affairs. Every year, several cooperative arrangements among IOs take place in cultural governance, ensuring several functions, such as technical assistance activities and policyoriented analysis, provision of financial assistance, building of conceptual frameworks, and data collection (Biermann and Siebenhüner 2013; Karns and Mingst 2015). However, even though the inter-organisational cooperative structures are several, they seem to have a short life cycle. Since 2000s, two prominent cases of cooperation among IOs have been both the EU-Mercosur audiovisual programme established in 2007 and the UN multi-agency group on creative industries created in 2004, bringing together five UN bodies: United Nations Conference on Trade and Development (UNCTAD), United Nations Educational, Scientific and Cultural Organisation (UNESCO), World 
Intellectual Property Organization (WIPO), International Labour Organization (ILO), as well as the United Nations Development Program (UNDP). At the beginning, both cooperation initiatives were ambitious in terms of objectives, but they did not last over time and did not succeed to establish sustainable cooperative structures (see supra section 2). In this view, we should reasonably ask the following question: when and why does not the cooperation between intergovernmental organisations last in global cultural governance?

The article seeks to approach inter-organisational cooperation in cultural affairs as an observable empirical phenomenon (Vlassis 2018, Vlassis and De Beukelaer 2019; Labadi 2020a). The goal is to explore when and why the cooperation between IOs risks not lasting and to understand why the dynamics of inter-organisational cooperation have a specific-time limit. Based on inductive research approach, the focus will be on two cases: the first case will deal with cooperation among regional organisations highlighting the EU-Mercosur audiovisual programme and the second case will emphasise the cooperation among UN bodies, dealing with the UN interagency group on creative industries. The two cooperative arrangements took place in the 2000s and 2010s, allowing us to take necessary analytical distance from the events. Moreover, both cases provide two ambitious interorganisational frameworks of cooperation, while they are quite different in terms of the number of actors and their respective historical backgrounds. In addition, the two selected cases have already been the object of analysis in a long list of thoughtful studies (De Beukelaer 2014a, 2014b; Canedo and Crusafon 2014; Schlesinger 2016; Fernandes et al., 2021; Vlassis 2016), showing their academic and empirical relevance and providing the opportunity to bring the article's arguments in a dialogue with the existing literature. As such, by opening the black box of the inter-organisational cooperation (Saurugger 2013), the article empirically analyses the purposes of the IOs' administrations and the factors, which prevent the sustainability of the inter-organisational cooperation in cultural affairs. The article is based on document analysis (reports, recommendations, IOs' drafts, newsletters, etc.) and on 15 semi-structured interviews with the actors involved, ${ }^{2}$ such as high-ranking officials from IOs, representatives from national governments and associations of culture professionals.

The article consists of four main parts. First, it provides a mapping of the ongoing research landscape regarding the role of IOs in global cultural governance and their cooperative arrangements and it introduces a conceptual alternative framework based on an actor-centred constructivist approach, by describing the research assumptions it developed to explain the central research question. Second, the article will deliver short descriptive analysis about EU-Mercosur audiovisual programme and the UN interagency group on creative industries. Thirdly, it delves into the process of cooperation among IOs, focusing on the argument that policy outcomes depend on three specific factors: the role of national governments and associations of culture professionals and how these actors influence the sustainability of frameworks of cooperation among IOs; the bureaucratic infighting and the scarcity of resources also explains why cooperation among IOs risks fading away; the need by IOs' administrations to enhance authority and credibility in a highly competitive environment can also prevent the establishment of consolidated cooperative structures among IOs. A final section summarises the key arguments and develops broader lessons this analysis holds for exploring the politics of global cultural governance.

\section{Global cultural governance and intergovernmental organizations: towards an actor-centred constructivist approach}

In order to explore the analytical importance of an actor-centred constructivist framework, it is necessary to highlight how the existing academic literature might account for the role of IOs in global cultural governance and the cooperation among IOs. The emerging literature brings together scholars from various disciplines, such as law, cultural and media studies, sociology and political science. It has produced a long list of thoughtful studies providing useful insights regarding the role and contribution of IOs in global cultural governance. A first part of this academic research remains widely law-oriented thereby adopting a state-centric viewpoint (Schorlemer and Stoll 2011; Kono 
and Van Uytsel 2012; Richieri Hanania 2014). A second part of the literature on IOs in cultural affairs highlights the normative role of IOs for mobilising resources and spreading ideas in global cultural governance. It notably focuses on political action of UNESCO (Vlassis 2013; De Beukelaer 2014b; Alasuutari and Kangas, 2020 2020), of UNCTAD (Isar 2008; De Beukelaer 2014a) and of languagedriven IOs, including the Organisation internationale de la Francophonie or the Comunidade dos Paises de Língua Portuguesa (Massart-Piérard 2007; Figueira 2018). A third part of this scientific research deals with the cultural diplomacy of regional organisations, as the EU (Pauwels and Loisen 2016; Carta and Higgott 2019) and Mercosur (Canedo 2013; Fernandes et al. 2021). It also focuses on the relationships among regional organisations, the outcomes of their cooperation and the contribution of the EU to disseminate cultural norms to other regional entities, as Mercosur or CARIFORUM (Canedo and Crusafon 2014; Sarikakis and Ganter 2014; Vlassis 2016; Garner 2017). Broadly speaking, this scientific literature is based on institutionalist and normative assumptions, which highlight the architecture of the global cultural governance and assess the overall institutional impact of the IOs in international cultural affairs, emphasising in which ways IOs should reframe the governance norms in cultural sectors. In addition, it focuses on how IOs interact with other actors, such as governments, experts or associations, exploring sufficiently the interplay between global cultural governance and IOs' practices.

For understanding when and why the cooperation among IOs fades away in global cultural governance, the present article aims to provide an alternative approach, aiming to complete legal and institutionalist assumptions. The explanation offered here brings in conversation political analysis with cultural policy perspective; based on an actor-centred constructivist approach (Acharya 2017; Saurugger 2013, 2016; Vlassis 2015), it suggests that the key assumptions of the emerging academic literature on IOs in cultural affairs leave little space for the discussion of politics in global cultural governance and seem to be too distant from the agents making cooperative arrangements. Thus, much work should be done for exploring cultural governance through political dynamics (Jenson and Mérand 2010, 74-79) and understanding how a changing political situation can open political possibilities for agents to 'modify the rules and institutions in which they act' (Saurugger 2016, 71-74). The article considers that the existing literature would benefit from a dose of thinking in terms of politics and of analysing the political micro-foundations of the cultural governance. In this respect, the politics in cultural governance should not be an unacknowledged element, something regarded as unproblematic; instead, the article is more concerned with highlighting the dynamics through which the cooperation between IOs takes place and with exploring the factors, which could undermine the establishment of long-term cooperative arrangements.

The article suggests that global cultural governance can be understood as a political process for organising the relations of power and of regulation with respect to activities of IOs and other actors involved at multiple levels - local, national, regional and global one (Weiss and Wilkinson 2019). Global cultural governance is composed of informal and formal ideas, norms, procedures and institutions (Karns and Mingst 2015, 2), affecting several aspects in the activities of the actors involved and allowing them to seek to coordinate their practices in a context of polyarchic authority (Avant, Finnemore, and Sell 2010) and of absence of global government (Rosenau 1997).

As such, the actor-centred constructivist approach is not so much a static approach for the today power relationships between involved actors in global cultural governance; instead, it sees the latter as a continuous process within which a constant game of bargaining, exchanges, and political confrontations is made (Puppis 2010; Vlassis 2015a). What can be derived from this is that cooperation among IOs does not emerge spontaneously from mandates of IOs or path-dependence decisions, but it is a political act, shaped by conflict and competing political worldviews that aim to promote their own values and objectives (Freedman 2008, 1-4).

To elaborate further, the goal is to analyse the cooperation between IOs 'in situ and in action' (Guiraudon 2000), exploring how the actors involved shape-specific views on problems and solutions. The cooperation between IOs is the result of a multiplex political process (Acharya 2017) marked by formulation of views, expressed by multiple actors that adhere to a certain logic about the 
scope and objectives of this cooperation and that engage in debate and negotiation within specific institutional frames. The actor-centred constructivism concentrates on how to understand the framing of inter-organisational cooperation through actor interaction (Vlassis and De Beukelaer 2019; Saurugger 2016). It is not only the institutional form of actors but their interactions with one another that shape governance outcomes. In other terms, neither norms nor ideas float freely (Risse 1994). The aim is to introduce politics into the emerging cultural governance studies literature, stressing that ideas and norms are not static elements of the institutional environment, but they are linked to actors and to their preferences. With this in mind, the cooperation between IOs is linked to the goals and resources of a wide variety of actors, who mobilise strategies and promote their set of ideas and norms.

Thus, the article treats the global cultural governance as political process rather than as structure. In this sense, if the cooperation among IOs is a process, it is worthwhile to ask ourselves who are the actors who are involved in the process, which kind of views these actors formulate and promote regarding the nature and objectives of the cooperation, as well as the perspectives that remain at the margins of this process.

\section{Inter-organizational cooperation in cultural affairs: two cases}

The EU-MERCOSUR audiovisual programme and the UN interagency group on creative industries are the two cases of inter-organisational cooperation that the article seeks to explore. In this section, the article delivers a short overview with respect to historic pathways of the two cases.

\section{EU-MERCOSUR audiovisual program}

In 1995, Mercosur and EU signed the Interregional Framework Cooperation Agreement, which entered into force in 1999. The article 21, entitled 'Cooperation regarding information, communication and culture' provided that, 'the Parties shall agree to strengthen the cultural links between them (...) such cooperation should seek to promote contact between the Parties' information and communications media in forms including technical assistance' (European Union-Mercosur 1999, 12). The turning point for the Mercosur audiovisual cooperation was the creation of the Reunión Especializada de Autoridades Cinematográficos y Audiovisuales del Mercosur (RECAM) in 2003.

The RECAM was an institutional instrument for strengthening the exchanges between national audiovisual authorities within the Mercosur and its goal was to harmonise normative frameworks in the audiovisual sector (Mercosur 2003). It's worth underlying that the interest for Mercosur audiovisual integration was strengthened by the EU insofar as 'the establishment of a regional agency responsible for audiovisual policy was the first EU requirement for any future EU-Mercosur cooperation' (Canedo and Crusafon 2014, 531). In 2007, the establishment of the Programa Mercosur Audiovisual (PMA), at the instigation of the European Commission, became a key moment for starting the consolidation of the Mercosur audiovisual integration. At the same time, the Foro de Competitividad del Sector Cinematográfico has been created in order to gather representatives from Mercosur national governments, audiovisual industries and professionals at regional level.

Under the 1995 Interregional Framework Cooperation Agreement currently in force, the EU provided the PMA with 1.5 million euros (total budget: 1.86 million euros). The aim of the programme was 'to strengthen the cinematographic and audiovisual sector in Mercosur as an instrument fostering the regional integration process and the participation of the civil society' (European Commission 2008a, 4). It was based on five axes: (i) carrying out comparatives studies on the legislation of the audiovisual sector in Mercosur Member States (MS); (ii) strengthening the capacities of the Observatorio Mercosur Audiovisual; (iii) the creation of a Mercosur network of 30 digital cinema theatres for exhibiting regional audiovisual content; (iv) support for the restoration, preservation and dissemination of the audiovisual heritage of Mercosur; (v) professional and technical training in the audiovisual sector. 
It's revealing that in 2007, the Regional Strategic Document of the European Commission explicitly pointed out that one of the priorities was the consolidation of the Mercosur audiovisual and cinematographic sector in order to promote the regional integration, emphasising that one expected outcome was 'the setting up of a Mercosur Media Program based on the EU MEDIA Program to provide incentives to encourage cooperation between agents in the sector to foster the joint development of works and their distribution and promotion within Mercosur' (European Commission 2007, 38).

\section{UN multi-agency group on creative industries}

The active involvement of UNCTAD in the discussions on the creative industries was one of the key goals of UNCTAD's secretariat (Isar 2008). Founded in 1964, UNCTAD's mission is to support developing countries for facilitating export diversification, increasing trade, and to strengthen ultimately development. As UNCTAD focused on the 'creative economy', the underlying was to further boost 'developing' countries' export diversification to drive their economic development. In 2004, at the UNCTAD XI Conference held in São Paulo, Brazil, the São Paulo Consensus, adopted by 153 MS, stressed, 'The international community should support national efforts of developing countries to increase their participation in and benefit from dynamic sectors and to foster, protect and promote their creative industries' (UNCTAD 2004, 19). Following the São Paulo Consensus, UNCTAD set up the UN multi-agency informal group on creative industries in an effort to build synergies with other relevant UN bodies. As mentioned above, the group brought together five IOs: UNCTAD, UNESCO, WIPO, ILO and the UNDP. Its aim was to provide knowledge-based activities with respect to creative industries. In 2007, UNCTAD has convened two meetings of the multiagency informal group (UNCTAD 2006-2012).

Two concrete outcomes of the UN informal group should be underlined: The first one was the launching of the Creative Economy Report during the 2008 UNCTAD XII Conference in Ghana, the first report by UN agencies for contributing to discussions about the creative economy. The aim of this policy-oriented analysis was to establish a framework, with a view to assist governments in formulating policies and to reshape the development agenda with creative industries in mind. UNCTAD took the lead in preparing the 2008 and 2010 reports on creative economy (UNCTAD 2008, 2010), bringing together contributions from UNCTAD, UNDP, UNESCO, WIPO and International Trade Center. However, the 2013 report on Creative economy was executed by UNESCO (UNESCO 2013), receiving only the financial contribution by UNDP. In addition, in 2019, UNCTAD individually released the Creative Economy Outlook (UNCTAD 2019), whereas in 2018, UNESCO individually published the Report 'Investing in Creativity'.

The second outcome was the project 'Strengthening the creative industries in five ACP countries'. The project was jointly implemented by UNCTAD, ILO and UNESCO, with financial aid from the EU and the institutional support from the Secretariat of the ACP Group. The beneficiary countries were five: Fiji, Mozambique, Senegal, Trinidad and Tobago and Zambia. The project intended to provide ways to stimulate the creative economies in developing countries through a variety of activities spread over 4 years (2008-2011). In 2011 UNCTAD, however, released individually two policyoriented reports with respect to Mozambique and Zambia, while the reports on the other beneficiary countries have not been prepared or released (UNCTAD 2006-2012).

\section{When and why does not the inter-organizational cooperation last?}

The article focuses on three key factors, which can contribute to the establishment of cooperative arrangements among IOs: (i) the role of national governments and groups of culture professionals; (ii) the bureaucratic frictions and the scarcity of - human, epistemic and financial - resources; as well as (iii) the need for consolidating the IO's authority in a highly competitive international environment. 


\section{EU-Mercosur audiovisual cooperation: bringing governments and societal groups back in the frameworks of cooperation}

In the 2010s, the funding from the EU to the PMA has not been renewed. The EU-Mercosur cooperation in audiovisual affairs faded away and the two regional organisations did not establish further cooperative arrangements following the implementation of the PMA. In order to understand why the effort to develop an interregional audiovisual cooperation did not last, it's important to put the EU-Mercosur cooperation in perspective with the multilateral audiovisual programme lbermedia. A closer analysis on the Iberoamerican audiovisual cooperation, which took place in parallel with the Mercosur audiovisual programme, shows that national governments have jealously sought to guard the audiovisual co-production area and their prerogatives in audiovisual affairs, highlighting at the same time the political and societal weaknesses of the audiovisual cooperation among two regional organisations.

The first formal documents related to the Iberoamerican audiovisual cooperation were signed in Caracas, Venezuela in November 1989 with the adoption of the Convenio de Integración Cinematográfica Iberoamericana, an agreement for deepening the audiovisual cooperation among the countries of the region and signed by 12 countries. ${ }^{3}$ The agreement established two institutional instruments: firstly, the Conference of Iberoamerican Cinematographic Authorities $(\mathrm{CACl})$, a multilateral agency for strengthening the Iberoamerican audiovisual cooperation, composed of the relevant public authorities and in charge of implementing the agreement; and secondly, the Executive Secretariat for the Iberoamerican Cinematography, which was the technical and executive organ, located in Caracas. In this regard, the $7^{\text {th }}$ Iberoamerican Summit of Heads of State (Margarita Island, Venezuela, 1997) approved the establishment of Ibermedia Program (Programa de desarrolló audiovisual en apoyo de la construcción del espacio visual iberoamericano). The program was part of the audiovisual policy of the $\mathrm{CACl}$ and it illustrated the political willingness of the participants to develop an institutional mechanism making the first steps for creating an Iberoamerican audiovisual area. Compared to the EU-Mercosur audiovisual cooperation, the initiative of establishing Ibermedia was taken by a national actor, 'the Spanish Ministry of Foreign Affairs and the Spanish Ministry of Culture' (Author's interview with a high-ranking official of Instituto Nacional de Cine y Artes Audiovisuales - INCAA (Argentina), 5 November 2015) and the creation of the program directly involving the national relevant authorities, which were at the forefront of the allocation of resources and the implementation.

In addition, unlike the EU-Mercosur audiovisual programme, two initiatives reveal that the groups of audiovisual professionals were dynamically and rapidly organised in the framework of the Iberoamerican audiovisual cooperation: firstly, the Mercado Iberoamericano de la Industria Audiovisual was established in 1995, whereas the Mercado del Film del Mercosur was put in place in 2005 (Crusafon 2011, 33); secondly, under the Spanish Federation of Audiovisual Producers' instigation and followed by the producers of Argentina, Mexico, and Venezuela, the creation of the Iberoamerican Federation of Film and Audiovisual Producers (Federación Iberoamericana de Productores Cinematográficos y Audiovisuales- FIPCA) occurred in 1997, while the establishment of an Asociación de Productores Audiovisuales del Mercosur took place in 2000.

The Iberoamerican Federation had two main goals: first, to support the Iberoamerican cooperation; second, to help the producers of Latin American region to be organized at national level and to exert pressure to national authorities for adopting legislations on the cinema sector. A successful example of our action was Colombia and the new Fund and legislation for the cinema sector (Author's interview with a high-ranking official of FIPCA, 4 November 2015).

In 1998, Ibermedia had 12 members: two EU MS, Spain and Portugal, three Mercosur MS, Argentina, Brazil and Uruguay, as well as seven other Latin American countries (Colombia, Cuba, Chile, Peru, Bolivia, Puerto Rico, Mexico, Venezuela). ${ }^{4}$ Ibermedia's goals were to financially assist filmmakers to promote distribution and exhibition of Iberoamerican films, as well as to sponsor exchanges and training of audiovisual professionals among Iberoamerican countries. With respect to the financial 
resources, each country contributed to the multilateral fund in accordance with its economic development in terms of audiovisual industries (minimum 100,000 USD). Unlike the PMA, Ibermedia possessed substantial resources; during the period 1998-2014, the total budget of the programme was 83 million USD and it supported more than 2050 projects including the sectors of the script development (757 projects), co-productions (679), formation (343), support for distribution and exhibition (238). Ibermedia's offices are in Madrid and Spanish government has contributed more than $40 \%$ of the total resources of the programme (36.6 million USD in total), followed by Brazil and Mexico (Paz Garcia 2011; Villazana 2008). ${ }^{5}$ Clearly, the multilateral programme Ibermedia was mainly inspired by the EU audiovisual programme MEDIA; as such, it represented a dynamic policy model transfer from the European region to the Iberoamerican one in terms of allocation of resources and quantity of supported projects compared to the EU-Mercosur audiovisual cooperation.

Spanish authorities created this Fund for catching the Latin-American movies. It was a win-win situation both for Spain and for the big Latin-American producer countries (Author's interview with a high-ranking official of the Cámara Argentina de la Industria Cinematográfica, 3 November 2015).

More specifically, during the period 1998-2014, the contribution by Brazil and Argentina, two key Mercosur MS, reached 8.8 million USD and 5.1 million USD, respectively (see Table 1). At the same time, Spain has been the main receiver of the Ibermedia's financial aid with $15 \%$ of the total resources (14.9 million USD), followed by Brazil (8.77 million USD) and Argentina (8.18 million USD).

Following the financial crisis in Spain, the Spanish contribution to Ibermedia has largely reduced. But in the 2000s and early 2010s, Ibermedia was the major fund of production (Author's interview with a high-ranking official of INCAA, 5 November 2015).

Clearly, the European Commission has sought to promote the EU audiovisual policy model within the Mercosur region; yet, this interest to push the Mercosur audiovisual integration forward has largely remained declaratory without being accompanied by substantial financial resources, political willingness from EU and Mercosur MS and support from cinema organisations. It's revealing that today the Foro de Competitividad del Sector Cinematográfico does no longer exist; likewise, the Mercado del Film del Mercosur has failed to attract cinema professionals, since the key priority of national audiovisual authorities and of cinema organizations within Mercosur region has been the Latin American Film Market Ventana Sur, ${ }^{6}$ which is a Latin American film market created in November 2009 by Argentina's relevant authorities (INCAA) and the Marché du Film de Festival de Cannes. In other terms, the European Union, as a more powerful actor in the cooperative arrangement, did not use a combination of necessary incentives and opportunity sets in order to secure interregional cooperation and to influence the Mercosur actors to behave in a desired way. On the flip side, the Iberoamerican audiovisual cooperation illustrates that a long-term cooperative arrangement in terms of resources and projects expects to involve three factors: the leadership of a powerful actor such as the Spanish government mobilizing substantial resources, the political and economic

Table 1. Ibermedia's resources by country, 1998-2014.

\begin{tabular}{lcc}
\hline Country/financial resources (in million USD) & Total contributed resources & Total received resources \\
\hline Spain & 36.67 & 14.92 \\
Brazil & 8.84 & 8.77 \\
Mexico & 5.95 & 6.33 \\
Venezuela & 5.51 & 6.37 \\
Argentina & 5.09 & 8.18 \\
Portugal & 4.25 & 5.01 \\
Colombia & 2.29 & 4.97 \\
Uruguay & 2.05 & 3.85 \\
Cuba & 2.00 & 3.93 \\
\hline
\end{tabular}

Source: Ibermedia. 
interest from national governments to follow the political entrepreneur and to be involved within the framework of cooperation, and the mobilization of the key recipients of the cooperation, being the organizations of cinema/audiovisual professionals.

\section{Intergovernmental organizations living in a competitive environment}

The domain complementarity of IOs on a specific issue can be a factor for a framework of interorganisational cooperation. In the 2000s and early 2010s the creative industries have become a shared-issue with exchanged competences among UNCTAD, UNESCO, WIPO, ILO, and UNDP. 'Without domain similarity, the sine qua non for cooperation is lacking' (Biermann 2008, 156). The multidimensional nature of the creative economy has overcome the mandate of an IO. On the flip side, UNCTAD had little experience regarding cultural affairs or intellectual property matters. Initiating cooperation on creative economy with relevant institutions helped, therefore, to reduce its policy uncertainty about a multifaceted issue.

Nevertheless, even though the above factor can generate inter-organisational cooperation, it cannot guarantee that the cooperative arrangement will not break down. In the following section, the analysis focuses on two additional factors, which trigger obstacles to sustain frameworks of cooperation: bureaucratic infighting and scarcity for resources; competition for leadership in order to ensure legitimacy and authority.

\section{Bureaucratic tensions and search for resources}

IOs derive power from their ability to claim and exercise authority through expertise, specialised knowledge and spread of collective norms, rather than from the traditional and hard attributes of state power. 'To be authoritative, ergo powerful, IOs must be seen to serve some valued and legitimate social purpose' (Barnett and Finnemore 2004, 21). IO's authority thus largely resides in the realm of producing and disseminating collective ideas (Oestreich 2012, 8). However, the consolidation of authority in a specific policy sector, as the creative industries, can generate bureaucratic infightings among UN agencies. In other terms, efforts for coordination inject 'an element of hierarchy', which often is resisted by autonomous IOs: 'Everyone wants coordination, but no one wants to be coordinated' (Jonsson 2012, 163).

In this view, UNESCO and WIPO, as specialised UN agencies, with their own specific agenda and budgets, produced their contributions to the 2008 and 2010 Reports with their own resources. On the one hand, WIPO took a traditional legalist approach based on intellectual property (IP) legislation and on the degrees of conformity of such legislation with international standards (Vlassis and De Beukelaer 2019). Instead, UNCTAD's objective was to take into consideration specific socio-economic circumstances of developing countries. According to UNCTAD officials, UNCTAD did not have the same approach as WIPO about intellectual property rights; WIPO focused on protecting the private sector in developed countries without considering the complaints of developing countries that some aspects of the current IP system discriminates against them (Author's interview with a high-ranking official, UNCTAD, 11 April 2016).

On the other hand, UNESCO, the only UN agency with a legitimate and clearly recognised interest in culture based on its mandate, saw the 'creative economy' as a market-oriented perspective, which risked calling into question the importance of cultural policies and the key principles of the Convention on the Protection and Promotion of the Diversity of Cultural Expressions (CDCE) adopted in 2005, such as the specificity of cultural goods and services and the importance of public intervention in cultural affairs (Vlassis 2015a). In fact, UNCTAD sought to go beyond the traditional cultural approach and the scope of core cultural industries, taking into account the process of technological convergence (Tremblay 2008, 83). In the words of a former high-ranking UNESCO official, when UNESCO administration talked about 'creative economy' within the organisation, the delegations of France, Canada and of other promoters of the CDCE appeared reluctant about the use of the new concept. Indeed, during the preparation of the 2008 Report, the main issue was its scope 
and the full list of creative industries, which formed the creative economy. According to WIPO and UNESCO officials, the goal of UNCTAD was to rely the Report on the United Kingdom (UK) perspective on creative industries (Garnham 2005), whereas WIPO and UNESCO already had a wellestablished approach about the cultural sector and its contribution to development. In other terms, the UN bodies had different perspectives on the creative industries and no consensus existed with respect to the definition of the 'creative economy'.

For instance, UNESCO does not consider software as creative industry. In WIPO perception, software is totally linked to copyright protection and the copyright is a mechanism to protect and promote creativity (Author's interview with a high-ranking official, WIPO, 19 April 2016)

As such, in the 2008 Report, the first - and conceptual - chapter entitled 'Concept and context of the creative economy' was drafted by David Throsby, an Australian cultural economist, and reviewed by Edna Dos Santos, UNCTAD high-ranking official (Vlassis and De Beukelaer 2019). It is revealing that this chapter did not outline a UN approach but it self-referentially focused on the 'UNCTAD classification of the creative industries'. This indicates how the attempt to create a common UN perspective failed due to inter-agency differences and disagreements on a common definition.

In addition, UNESCO and WIPO felt that their respective positions were being weakened and did not endorse the Reports' conclusions (Vlassis and De Beukelaer 2019). According to interviewed officials, UNCTAD's attempt at leadership in an area related to cultural industries seemed no relevant. WIPO and especially UNESCO perceived UNCTAD as a multilateral competitor, which aimed to encroach upon their policy field and deal with a topic derived from their mandate. These tensions also eliminated certain perspectives from the Reports. The ILO, for example, participated in several sessions of the UN multi-agency informal group on creative industries. But the organisation, which could deal with employment and creative industries did not contribute to the Report due to administrative issues and to the scarcity of ILO human resources devoted to the issue of creative economy (Author's interview with a high-ranking official, UNESCO, 31 May 2016). In a similar vein, the ILO also had a different perspective about the definition of the creative industries. The UNCTAD objective was to deliver a broad definition including several sectors beyond the core cultural industries and hence to translate the creative industries into a major issue for the international development agenda. The ILO, however, functions according to organisation's mandate, strongly linked to trade unions of broadcasting, music and media sectors.

The creative economy was beyond our (ILO's) interests. ILO's definition is close to the definition of UNESCO, focusing on the artistic and cultural content to a large extent. WIPO and UNCTAD have an interest to say that $20 \%$ of GDP is related to creative economy. ILO has a more restrictive view on creative economy. The cultural perspective and the intellectual property perspective are different (Author's interview with a high ranking official, ILO, 8 June 2016).

Indeed, the IOs are meaningful actors in global cultural governance, searching for and mobilising resources. Regarding the interagency project 'Strengthening the creative industries in five ACP countries' (see supra section 2), the factors explaining this initiative are linked both to the particular interests of the IOs' administrations and to external pressure from the ACP countries. Yet, even though an $1 O$ can engage in a common project, the search for resources and legitimacy in a competitive environment could result in changing policy priorities. In the case of Mozambique and Senegal, UNCTAD began to prepare the report, but whereas UNESCO was involved in the interagency cooperation, it started at the same time dealing with other projects towards culture and development, receiving substantial economic resources from the Spanish government (Author's interview with a high-ranking official, UNCTAD, 11 April 2016). It's worth noting that in 2007 and in relation to the Millennium Development Goals (MDGs), the Spanish Agency of International Cooperation for Development supported 18 joint programmes ${ }^{7}$ linked to the issue of 'Culture and Development' with a financial allocation of 95.6 million USD (Labadi 2020b). The programme dealt with a wide range of cultural policy fields, such as cultural industries, cultural heritage and cultural tourism, and were implemented in 18 countries in Africa, Asia, Arab region, Europe, and in Latin 
America. UNDP and UNESCO played a key role and received more than $60 \%$ of the total allocation. UNESCO was involved in implementing all the joint programmes and the MDGs project on 'Culture and Development' became a policy priority for the organisation. ${ }^{8}$

In Mozambique, UNCTAD came with the common UN project but in some ways, it was excluded. It's the dynamics you see in the ground. UNDP and UNESCO have offices in every country, UNCTAD has in New York and Geneva. They are stronger than us. There were also strong differences in terms of implementation and impact of the project (Author's interview with a high ranking official, UNCTAD, 11 April 2016).

As shown in the UN inter-agency project in ACP countries, the involvement of IOs in the cooperative arrangements with other IOs risks being short-term, insofar as a priority of each IO is to adapt its expectations according to changing political circumstances and to ensure effective ways to deal with potential scarcity of resources in a competitive environment. The key objective of each organisation involved in a framework of cooperation is to consolidate - and preserve - its own legitimacy in the respective policy field and to enhance its credibility within the UN system vis-à-vis other UN bodies that also lobby for a better position of their policy agenda in the UN context.

\section{Competition for leadership}

The 2008 and 2010 Reports are based on two principles: advocating for the development dimension of the creative economy through trade diversification, and emphasising a macroeconomic approach through the elaboration of a statistical database (De Beukelaer 2014a). The UNCTAD goal through the release of the Creative Economy Reports was to increase the visibility of the cultural and creative industries in international development agenda, strengthening its image as a key 'development' institution within the UN system (Vlassis and De Beukelaer 2019). In fact, UNCTAD faced a political dilemma: As a bureaucratic organisation with neither substantial resources nor expertise and authority in the cultural fields, relying on the technical expertise of other IOs was necessary to carry out the Report. But, taking the lead was also essential for UNCTAD in order to get access to economic resources. Hence, the goal of the organisation was to justify its leadership, to leave its mark on the topic and to address it through the development perspective of UNCTAD's mandate.

Since creative industries moved to the top of UNCTAD's agenda, all organisations strove to demonstrate their specific expertise on the matter and better position themselves in this new topic (Author's interview with a high-ranking official, UNESCO, 31 May 2016). In 2013, UNESCO and UNDP published a 'Special Edition' of the Creative Economy Report with the subtitle Widening Development Pathways. This edition focused less on quantitative data on creative industries (as 2008 and 2010 Reports had) than on a qualitative analysis emphasising the local level and a grassroots approach.

The key question of the 2013 Report was 'how to capture the vibrancy and scale of creative economies beyond economic indicators' (UNESCO-UNDP 2013, 16). In this sense, UNESCO's focus on the 'creative economy' did differ from the perspective UNCTAD had previously advanced. First, the 2013 Report was built on UNESCO's previous normative framework: the report Our Creative Diversity, produced by the World Commission on Culture and Development and published in 1995; the 1998 Stockholm Intergovernmental Conference on Cultural Policies for Development, entitled The Power of Culture; and, most importantly, the 2005 CDCE, which recognizes both the importance of the specificity of cultural goods and services and of cultural public policies for the diversity of cultural expressions and includes provisions for the link between culture and development. UNESCO thus connected the creative economy to its own long-standing framework of dealing with culture and development. In doing so, UNESCO integrated the 'creative economy' into existing norms and practices of the organization - legitimising the creative economy as a part of UNESCO's work and criticising the way in which UNCTAD defined the concept and designed the Report.

From an actor-centred perspective, UNCTAD's move into the realm of international cultural affairs (through the 'creative economy') undermined UNESCO's position and legitimacy as a leading UN agency in global cultural governance (Hanrieder 2015). UNCTAD's action in creative 
industries could call into question the perception of other actors, such as States, civil society or experts, regarding the position of authority of UNESCO in cultural affairs (Barnett and Finnemore 2004, 25). In other terms, the UNCTAD's leadership in creative economy could influence whether UNESCO remains relevant as the focal arena for States' efforts to coordinate cultural policies and hereby affect the capacity of UNESCO to develop new rules and norms in global cultural governance (Tallberg and Zürn 2019, 582). In response, UNESCO needed to ensure its political relevance to governments and other stakeholders in a more competitive institutional environment. 'To being in a "vertical" relationship with States, international organisations are also in a "horizontal" relationship with other organisations, and need to respond to both competitive and complementary interaction with other institutions' (Betts 2012, 137). UNESCO aimed to show through several practices that the agenda on creative industries had become increasingly incorporated into the normative framework of the organisation. The 2013 Report devoted ample space for an evidence base drawn from previous experiences of UNESCO and UNDP. This included the International Fund for Cultural Diversity, a multi-donor fund established under Article 18 of the CDCE (Albornoz 2016) on one side, and on the other side, the Thematic Window on Culture and Development funded by the UNDP-Spain MDGs Achievement Fund and implemented by UNESCO and UNDP (see supra section $3 \mathrm{Ba}$ ).

UNESCO did have a further reason to pursue the particular focus of the 2013 Special Edition. It tried to use the 'Special Edition' of the Creative Economy Report as a political platform to advocate for the inclusion of culture in the post-2015 UN development agenda (Author's interview with a highranking official, UNESCO, 18 March 2016). UNESCO assumed responsibility for the Special Edition because of the UNESCO secretariat's interest rather than of member-state pressure. Through the 2013 Report, UNESCO aimed to highlight the importance of the 'creative economy' in development, by illustrating and discussing existing practices of the organisation in developing countries. In this regard, the 2013 Report was largely based on UNESCO's policy objective to persuade a critical mass of actors about the major role of culture as a driver of sustainable development and on its desire to promote its policy agenda within the UN system (Vlassis 2015b, 2017). The press release accompanying the publication of the report explicitly stressed that 'the report was launched as a major contribution to shaping a new and bold sustainable development agenda to follow 2015 that recognises the power of culture as an enabler and a driver' (UNESCO 2013).

Indeed, each organisation establishes its own priorities and working with others may mean restricting its authority. Controlling the guidelines of its own agenda and defining its strategy, without losing autonomy and putting in question its reservoir of confidence in the institution (Tallberg and Zürn 2019,11 ) remain a key motivation of each IO administration. It's revealing that even though a priority of ILO is the working conditions of artists in the new digital context, UNESCO's Secretariat does not seek cooperation in this policy field, insofar as its priority is the promotion of the UNESCO's CDCE as a central normative instrument within the global cultural governance.

The only thing that UNESCO wants is to incorporate the aspects of the Recommendation regarding the Status of the Artist in the work on the 2005 CDCE. My looking is that the CDCE is very weak about the conditions of artists. But there is no official structure in order to develop something. (Author's interview with ILO high-ranking official, 13 May 2016).

\section{Concluding remarks}

The cooperation among IOs in cultural affairs does not drop from the sky neither emerge in some organic and automatic way from State interests or IOs' mandates. Once we move beyond normative and institutionalist assumptions of the inter-organisational cooperation, the political microfoundations of this cooperation loom large. Thinking about the politics of global cultural governance has the useful effect of casting this governance in a new light. As such, embracing an actor-centred 
constructivist perspective, putting the spotlight on agents of the inter-organisational cooperation and 'making the dynamics of their authority' (Avant, Finnemore, and Sell 2010, 360) central to analysis highlight issues that deserve more consideration from scholars. The picture that emerges sheds light on three key points.

Firstly, the emergence of inter-organisational cooperation arrangements is by its very nature a contested process and one that is a long-term endeavour (Avant, Finnemore, and Sell 2010; Tallberg and Zürn 2019). The IOs are meaningful actors, which seek to ensure their legitimacy and strengthen their credibility in a competitive international environment. The key to understand the dynamics of the inter-organisational cooperation in cultural affairs is the interaction between different players involved in this political process of negotiation and legitimation. On the one hand, the IOs need to cope with a proliferation of multilateral activities (e.g. Ibermedia), that allows dissatisfied actors to give support to activities, which are closer to their perspective and preferences. However, inter-organisational cooperation in cultural affairs comes under high pressure, insofar as IOs increasingly need to justify their own practices in a specific policy field, such as the cases of UNESCO and UNCTAD. In a long-term period, cooperation among IOs can generate normative overlapping and institutional hierarchy, contesting the performance and thereby the legitimacy of IOs in their own policy sector.

Secondly, whereas the setting up of both Ibermedia and Mercosur Audiovisual Program were based on the EU audiovisual policy model, the absence of political entrepreneur for moving the Mercosur film cooperation forward, the lack of pressure from the organisations of audiovisual professionals as well as the reluctance by the national authorities have resulted in a very limited and feeble audiovisual cooperation between EU and Mercosur. The Iberoamerican cooperation showed that the leadership by a political entrepreneur as the Spanish government mobilising substantial incentives, the interest from national governments to follow the agenda-setter and to be involved within the framework of cooperation, and the grass-roots support from the organisations of cinema/audiovisual professionals are key factors for the inter-organisational cooperation.

Third, the tensions in institutional priorities with respect to the definition and scope of the creative economy made it impossible to articulate a unified UN perspective on the topic. The case of UN multi-agency group in creative industries showed that in a long-term period, an IO avoids inter-organisational cooperation, insofar as it could risk losing legitimacy, calling into question its own authority in cultural affairs, as the case of UNESCO. For the latter, in a context of political battles, the cooperation among IOs regarding the creative economy could enhance multilateral competitors, such as the UNCTAD, and influence whether UNESCO remains relevant as the focal arena for States and other actors to deal with key issues in global cultural governance. In this sense, in the long term, the IOs prefer to pursue unilaterally their preferences and not through agenda coordination. Otherwise, a long-term cooperation can entail a certain loss of autonomy and control on their own policy agenda, affecting capacity to attract resources in a competitive institutional environment.

Indeed, investigating political dynamics is undoubtedly context conditioned. Generalisations about them must therefore be contingent (Avant, Finnemore, and Sell 2010,368) and we should expect surprises as we explore other similar processes 'in situ and in action'. In this view, the foregoing analysis is a first investigation into the politics of cooperation among IOs. The hope here is to provide some initial study that will open up these ideas to more sustained research. Central among these ideas is that the political micro-foundations of the global cultural governance profoundly shape the outcomes of the cooperation among IOs. Much research remains to be done on the way in which at the international-level IOs promote their worldviews about global cultural governance and forge alliances with other actors involved, such as national governments, experts, private companies and civil society organisations. The ongoing UNESCO negotiations on a Recommendation on the ethics of artificial intelligence or the plurilateral negotiations on electronic commerce within the World Trade Organization are expected to have strong implications in cultural governance and they are relevant cases. A second important line of research would explore in which ways IOs promote their ideas and norms in different institutional contexts at various levels and the factors that are beneficial or obstruct 
the achievement of their aims. Here, the spread of creative economy or the political process of transposition of CDCE's norms in national and local institutional contexts are crucial cases. Thirdly, it is worth investigating how the framing of issues in global cultural governance comes from in the first place. In other terms, it is necessary to understand when and how specific ideas emerge (or not) in the political debate, by which kind of actors these ideas are developed and promoted and in which ways they are diffused. For instance, today an international debate about boosting cultural discoverability and visibility (McKelvey and Hunt 2019; Vlassis 2021) of local and national cultural content in the digital environment is not emerging within IOs and it is worth exploring why the political debate is not framed in that way. Finally, it is crucial to explore whether the sector of arts/culture/creative industries makes the cooperation among IOs different and more likely to break down, compared to other domains, as environment. For instance, we could contemplate that the scarcity of resources in the cultural cooperation among IOs could also reflect national contexts in which the resources allocated to culture remain low compared to those for environmental issues. In this view, it's worth investigating whether the 'cultural' in global cultural governance matter or the three factors analysed in the article can be applicable independent of the domain. In addition, the above four lines of research should also be problematised through the current political shift, which has unleashed a delegitimating reaction and domestic contestation towards the very existence of global governance and the prominence of international and regional organisations (Hooghe, Lenz, and Marks 2019).

Overall, the actor-centred constructivist approach is not a static perspective about global cultural governance. Instead, it provides an 'in situ and in action' view on norms and institutional arrangements that aim to organise the power relationships of involved actors. It allows for discussing the interplay between the normative outcomes and the political framing, exploring the competitive coalitions, their arguments, interactions and strategies. The actor-centred constructivist approach promises to be fruitful for exploring why and how the frameworks of cooperation are built under specific political conditions. Scholars in cultural policy studies can truly benefit from this approach in order to view cultural governance as political process, which is composed of bargaining, persuasion and framing between actors involved.

\section{Notes}

1. The term 'Intergovernmental organizations' (IOs) work better for UN bodies such as UNESCO or UNCTAD, rather than for regional organizations, such as the EU which includes partially supranational organs. For the needs of the research, the IOs include both international organizations such as UN bodies and regional organizations, such the EU or MERCOSUR.

2. The results of the interviews will be anonymously presented for reasons of confidentiality.

3. Argentina, Bolivia, Brazil, Colombia, Cuba, Ecuador, Mexico, Nicaragua, Panama, Peru, Spain, and Venezuela.

4. Today, the Ibermedia's members are 21: Argentina, Bolivia, Brazil, Colombia, Costa Rica, Cuba, Chile, Dominican Republic, Ecuador, El Salvador, Guatemala, Mexico, Nicaragua, Panama, Paraguay, Peru, Portugal, Puerto Rico, Spain, Uruguay, and Venezuela.

5. Regarding financial resources, the data is available from 1998 to 2014.

6. Ventana Sur receives more than 2000 accredited members.

7. In the UN context, a 'Joint Program' is a program involving two or more agencies.

8. The above analysis shows that all the three factors could be observable in both frameworks of interorganizational cooperation. However, the goal of the article is to provide a valuable empirical study of both cooperative arrangements; in this sense, the EU-Mercosur audiovisual cooperation deals deeper with the first factor and the UN multi-agency group on creative industries is concerned with the two other sets of factors.

\section{Disclosure statement}

No potential conflict of interest was reported by the author(s). 


\section{Notes on contributor}

Antonios Vlassis is Senior Researcher at the Center for International Relations Studies (CEFIR), University of Liège and Lecturer at the Department of Political Science, University of Liège. His research and teaching fields deal with international cultural cooperation, global cultural politics, EU cultural and media policies.

\section{References}

Acharya, A. 2017. After Liberal Hegemony: The Advent of a Multiplex World Order. Cambridge: Cambridge University Press. Alasuutari, P., and A. Kangas. 2020. "The Global Spread of the Concept of Cultural Policy." Poetics 82 doi:10.1016/j. poetic.2020.101445. Available online 25 May 2020.

Albornoz, L. A. 2016. "The International Fund for Cultural Diversity: A New Tool for Cooperation in the Audiovisual Field." International Journal of Cultural Policy 22 (4): 553-573. doi:10.1080/10286632.2015.1008467.

Avant, D., M. Finnemore, and S. Sell. 2010. Who Governs the Globe? New York: Cambridge University Press.

Barnett, M., and M. Finnemore. 2004. Rules for the World: International Organizations in Global Politics. Ithaca and London: Cornell University Press.

Betts, A. 2012. “UNHCR, Autonomy, and Mandate Change." In International Organizations as Self-Directed Actors, edited by J. Oestreich, 118-140. New York: Routledge.

Biermann, F., and B. Siebenhüner. 2013. "Problem Solving by International Bureaucracies: The Influence of Inter-national Secretariats on World Politics." In Routledge Handbook of International Organizations, edited by B. Reinalda, 149-161. London: Routledge.

Brosig, M. 2011. "Overlap and Interplay between Inter- National Organizations: Theories and Approaches." South African Journal of International Affairs 18 (2): 147-167. doi:10.1080/10220461.2011.588828.

Canedo, D. 2013. "Is Everybody against Hollywood? Policies, Networks and Film Flows of the Mercosur Film Space and the Cooperation with European Union." PhD Thesis, Universidad Federal Da Bahia and Vrije Universiteit Brussel.

Canedo, D., and C. Crusafon. 2014. "The European Audiovisual Policy Goes Abroad: The Case of Inter-regional Cooperation with Mercosur." In The Palgrave Handbook of European Media Policy, edited by K. Donders, C. Pauwels, and J. Loisen, 526-541. London: Palgrave MacMillan.

Carta, C., and R. Higgott, eds. 2019. Cultural Diplomacy in Europe: Between the Domestic and the International. London: Palgrave Macmillan.

Crusafon, C. 2011. "El espacio audiovisual euro-latinoamericano: El cine como eje central de la cooperación supranacional." Anàlisi 41: 27-45.

De Beukelaer, C., and K.-M. Spence. 2019. Global Cultural Economy. London: Routledge.

De Beukelaer, C. 2014a. "Creative Industries in 'Developing Countries': Questioning Country Classifications in the UNCTAD Creative Economy Reports." Cultural Trends 23 (4): 232-251. doi:10.1080/09548963.2014.912043.

De Beukelaer, C. 2014b. "The UNESCO/UNDP 2013 Creative Economy Report: Perks and Perils of an Evolving Agenda." The Journal of Arts Management Law, and Society 44 (2): 90-100. doi:10.1080/10632921.2014.895789.

European Commission. 2007. "Mercosur Regional Strategy Paper 2007-2013." E/2007/1640, 02 August.

European Commission (2008a), Preparatory Action Mercosur Audiovisual Program, Brussels, DCI/ALA/2008/020297.

European Union-Mercosur. 1999. Interregional Framework Cooperation Agreement between the European Community and Its Member States; of the One Part, and the Southern Common Market and Its Party States, of the Other Part. Brussels: 22 March.

Fernandes, M. R., J. Loisen, and K. Donders. 2021. "Mercosur Caught between Lofty Ambitions and Modest Achievements: A Critical Analysis of 16 Years of Audiovisual Policy-making." International Journal of Cultural Policy 27 (4): 544-558.

Figueira, C. 2018. "Cultural Policy between and beyond Nation-states: The Case of Lusophonia and the Comunidade Dos Paises de Lingua Portuguesa." In The Routledge Handbook of Global Cultural Policy, edited by V. Durrer, T. Miller, and D. O'Brien, 133-147. London: Routledge.

Freedman, D. 2008. The Politics of Media Policy. Cambridge: Polity Press.

Garner, B. 2017. "Towards a European Strategy on Culture and Development. Learning from the CARIFORUM-EU Economic Partnership Agreement." Politique européenne 56 (2): 146-168. doi:10.3917/poeu.056.0146.

Garnham, N. 2005. "From Cultural to Creative Industries: An Analysis of the Implications of the "Creative Industries" Approach to Arts and Media Policy Making in the United Kingdom." International Journal of Cultural Policy 11 (1): 15-29. doi:10.1080/10286630500067606.

Guiraudon, V. 2000. "European Integration and Migration Policy: Vertical Policy-making as Venue Shopping." JCMS: Journal of Common Market Studies 38 (2): 251-271.

Hanrieder, T. 2015. "WHO Orchestrates? Coping with Competitors in Global Health." In International Organizations as Orchestrators, edited by K. W. Abbott, 191-213. Cambridge: Cambridge University Press.

Hooghe, L., T. Lenz, and G. Marks. 2019. "Contested World Order: The Delegitimation of International Governance." The Review of International Organizations 14 (4): 731-743. doi:10.1007/s11558-018-9334-3. 
Isar, Y. R. 2008. "The Intergovernmental Policy Actors." In The Cultural Economy, edited by H. K. Anheier and Y. R. Isar, 108-120. London: Sage Publications.

Jenson, J., and F. Mérand. 2010. "Sociology, Institutionalism and the European Union." Comparative European Politics 8 (1): 74-92. doi:10.1057/cep.2010.5.

Jonsson, C. 2012. "Changing Actors and Actions in Global Fight against AIDS." In International Organizations as SelfDirected Actors, edited by J. Oestreich, 141-166. New York: Routledge.

Karns, M., and K. Mingst. 2015. International Organizations: The Politics and Processes of Global Governance. London: Lynne Rienner.

Kono, T., and S. Van Uytsel, eds. 2012. The UNESCO Convention on the Diversity of Cultural Expressions: A Tale of Fragmentation in International Law. Helsinki: Intersentia.

Labadi, S. 2020a. The Cultural Turn in International Aid: Impacts and Challenges for Heritage and the Creative Industries. London: Routledge.

Labadi, S. 2020b. "UNESCO, Culture, Aid and Development in the New Millennium." In The Cultural Turn in International Aid: Impacts and Challenges for Heritage and the Creative Industries, edited by S. Labadi, 73-88. London: Routledge.

Massart-Piérard, F. 2007. "La Francophonie, un nouvel intervenant sur la scène internationale." Revue internationale de Politique comparée 14 (1): 69-93. doi:10.3917/ripc.141.0069.

McKelvey, F., and R. Hunt. 2019. "Discoverability: Toward a Definition of Content Discovery through Platforms." Social Media + Society 5 (1): 205630511881918. First Published Online 21 January. doi:10.1177/2056305118819188.

Mercosur. 2003. "Creacion de La RECAM." MERCOSUR/GMC/RES. N49/03.

Oestreich, J. 2012 "Introduction", in J. Oestreich (ed.) "Introduction". New York: Routledge, pp. 1-25 .

Pauwels, C., and J. Loisen. 2016. "Leading by Example? European Union Implementation of Cultural Diversity in Internal and External Audiovisual Policies." Javnost-The Public 23 (2): 153-169. doi:10.1080/13183222.2016.1162980.

Paz Garcia, C. 2011. "El Agotamiento Del Modelo Cinematográfico Analógico: Distribución Y Exhibición Digital: Un Nuevo Marco Para La Cooperación Audiovisual Iberoamericana." PhD Thesis, Universidad Complutense de Madrid.

Puppis, M. 2010. "Media Governance: A New Concept for the Analysis of Media Policy and Regulation." Communication, Culture \& Critique 3 (2): 134-149. doi:10.1111/j.1753-9137.2010.01063.x.

Richieri Hanania, L., ed. 2014. Cultural Diversity in International Law: The Effectiveness of the UNESCO Convention on the Protection and Promotion of the Diversity of Cultural Expressions. London: Routledge.

Risse, T. 1994. "Ideas Do Not Float Freely: Transnational Coalitions, Domestic Structures, and the End of the Cold-war." International Organization 48 (2): 185-214. doi:10.1017/S0020818300028162.

Rosenau, J. 1997. Along the Domestic-Foreign Frontier, Exploring Governance in a Turbulent World, 467. Cambridge: Cambridge University Press.

Sarikakis, K., and S. Ganter. 2014. "Priorities in Global Media Policy Transfer: Audiovisual and Digital Policy Mutations in the EU, MERCOSUR and US Triangle." European Journal of Communication 29 (1): 17-33. doi:10.1177/ 0267323113509360.

Saurugger, S. 2013. "Constructivism and Public Policy Approaches in the EU: From Ideas to Power Games." Journal of European Public Policy 20 (6): 888-906. doi:10.1080/13501763.2013.781826.

Saurugger, S. 2016. "Sociological Approaches to the European Union in Times of Turmoil." JCMS: Journal of Common Market Studies 54 (1): 70-86. doi:10.1111/jcms.12330.

Schlesinger, P. 2016. "The Creative Economy: Invention of a Global Orthodoxy." Les Enjeux de L'information and de La Communication 17 (2): 187-205. doi:10.3917/enic.021.0187.

Schorlemer, S., and P.-T. Stoll, eds. 2011. The UNESCO Convention on the Protection and Promotion of the Diversity of Cultural Expressions - Explanatory Notes. Berlin: Heidel- berg: Springer-Verlag.

Tallberg, J., and M. Zürn. 2019. "The Legitimacy and Legitimation of International Organizations: Introduction and Framework." The Review of International Organizations 14 (4): 581-606. doi:10.1007/s11558-018-9330-7.

Tremblay, G. 2008. "Industries culturelles, économie créative et société de l'information." Global Media Journal - Edition Canadienne 1 (1): 65-88.

UNCTAD. 2004. "Sao Paulo Consensus." TD/410, UNCTAD, 25 June.

UNCTAD. 2006-2012. "Creative Economy Programme: E-Newsletter," n¹-18.

UNCTAD. 2008. Creative Economy Report 2008. The Challenge of Assessing the Creative Economy: Towards Informed PolicyMaking. New York: United Nations.

UNCTAD. 2010. Creative Economy Report 2010. Creative Economy: A Feasible Development Option. New York, United Nations.

UNCTAD. 2019. Creative Economy Outlook: Trends in International Trade in Creative Industries. New York: United Nations.

UNESCO-UNDP. 2013. Creative Economy Report 2013 Special Edition: Widening Local Development Pathways. New York: UNESCO-UNDP.

UNESCO. 2013. Creative Industries Boost Economies and Development Shows UN Report. Press release, 14 November.

Villazana, L. 2008. "Hegemony Conditions in the Coproduction Cinema of Latin America: The Role of Spain." Framework: The Journal of Cinema and Media 49 (2): 65-85. doi:10.1353/frm.0.0021.

Vlassis, A. 2013. "L'UNESCO face à l'enjeu "commerce-culture": quelle action politique pour une organisation internationale?" Politique et Sociétés, 32(3): 81-101. 
Vlassis, A. 2015 Gouvernance mondiale et culture: de l'exception à la diversité. Liège: Presses de l'Université de Liège. Vlassis, A. 2016. "Organizaciones regionales y diversidad cultural: la diplomacia de la Unión Europea con el Mercosur entre la sombra de Hollywood y la acción intergubernamental". Cuadernos de Información y Comunicación, 21: 97-115.

Vlassis, A. 2018. "The international politics of the nexus 'culture and development': four policy agendas for whom and for what?" In V., Durrer, T., Miller, and D., O'Brien, The Routledge Handbook of Global Cultural Policy. London, United Kingdom: Routledge, pp. 417-429.

Vlassis, A. 2021. Global online platforms, COVID-19, and culture: The global pandemic, an accelerator towards which direction? Media, Culture and Society, 43(5): 957-969.

Vlassis, A., and De Beukelaer, C. 2019. "The creative economy as a versatile policy script: exploring the role of competing Weiss, T., and R. Wilkinson. 2019. Rethinking Global Governance. Medford: Polity Press. 